\title{
Eccrine hidrocystoma: A brief report
}

\section{Chandramohan Kudligi', Vidya Kuntoji ${ }^{2}$, Pradeep Bhagwat ${ }^{1}$, Suphala B Raj ${ }^{3}$}

\author{
${ }^{1}$ Department of Skin and STD, Karnataka Institute of Medical Sciences, Hubli, Karnataka, India, ${ }^{2}$ Department of Skin \\ and STD, Gadag Institute of Medical Sciences, Gadag, India, ${ }^{3}$ Consultant Dermatologist and Cosmetologist, TSS \\ Hospital, Sirsi, India
}

Corresponding author: Dr. Vidya Kuntoji, E-mail: drvidyakuntoji@gmail.com

Sir,

A 48 year old female presented to us with multiple asymptomatic papules around eyes since 15 days. She had similar complaints from past 4 years. She gave history of exacerbation of these lesions in summer season and spontaneous remission in rainy season. There were no systemic complaints. On cutaneous examination, multiple translucent dome shaped papules of nearly $0.5 \mathrm{~cm}$ were present in peri orbital area (Fig. 1). Systemic examination was normal. Simple puncture of a papule with a sterile needle exuded small amount of serous clear fluid. Routine investigations were under normal limits. Histopathology suggested unilocular dermal cystic lesion lined by two layers of cells lined by cuboidal cells. The features were suggestive of Eccrine Hidrocystoma.

Hidrocystomas are rare benign cystic skin tumours. They are classified as Eccrine and apocrine Hidrocystomas. While the former represent retention cysts of the Eccrine duct, the latter arise from the apocrine secretory coil [1]. Eccrine Hidrocystomas (EC) are of two types; the classic Robinson type (multiple type) named after his first discovery of EC in women with multiple facial lesions who were working in hot and humid environment and the Smith and Chernosky type (solitary type) named after Smith and Chernosky who reported patients with a solitary lesion [2]. They are seen predominantly on face, usually in periorbital area as cystic papules of about $1-3 \mathrm{~mm}$ in diameter. However head, trunk and popliteal fossae may also be affected [2]. It is prevalent in adults between 30 and 70 years of age and shows predilection for females, more so with the multiple type [3]. The peculiarity of EC is that the lesions worsen in summer

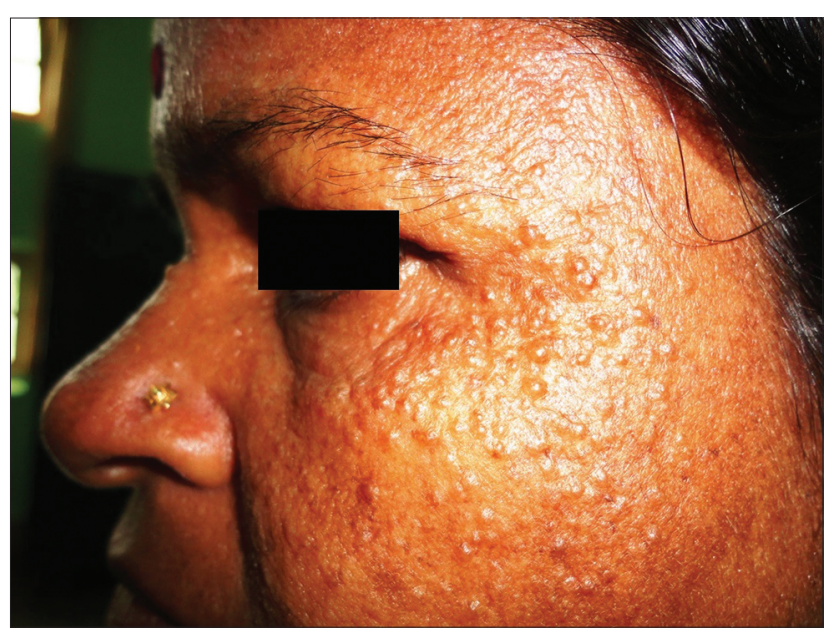

Figure 1: Multiple dome shaped translucent papules in periorbital area.

and remit in winter. Its exact pathogenesis is not elucidated. However the hypotheses proposed are poral closure causing secondary dilatation of sweat duct or adenomatous proliferation of the excretory duct [4]. Although apocrine hidrocystomas (AH) can mimic EH clinically, there are certain differences to be noted. The cysts in AH are usually larger, with a diameter of 3 to $15 \mathrm{~mm}$, darker blue in colour and they are more often seen along the eyelid margin near the inner canthus rather than the periorbital region. Unlike EC, no seasonal variation is seen and they are usually solitary at presentation although there are reports of multiple lesions over face, forearms, anterior chest, axillae and labia majora [5]. Histopathology aids in confirming the diagnosis. AC are multilocular cysts in the dermis lined by myoepithelial cells and secretory columnar cells with decapitation secretion. The cysts have papillary projections and periodic acid Schiff (PAS) positive and diastase-resistant granules in secretory cells. EC usually 
have a single cystic cavity lined by two layers of cuboidal cells. They do not feature myoepithelial cells, papillary projections, decapitation secretion and PAS positive diastase resistant granules [6]. Treatment options include simple needle puncture which gives temporary improvement, microdermabrasion, electrodessication. There are few reports of improvement with topical atropine and scopolamine, pulsed dye laser and botulinum toxin A [7].

\section{CONSENT}

The examination of the patient was conducted according to the Declaration of Helsinki principles.

\section{REFERENCES}

1. Kikuchi K, Fukunaga S, Inoue H, Miyazaki Y, Ide F, Kusama K. Apocrine Hidrocystoma of the Lower Lip: A Case Report and
Literature Review. Head Neck Pathol. 2014;8:117-21.

2. Ghosh SK, Bandyopadhyay D, Biswas SK, Mandal RK. Multiple translucent papules on the face of a middle-aged woman. Indian J Dermatol Venereol Leprol. 2010;76:721-2.

3. Kaur C, sarkar R, kanwar AJ, Mohan H. Multiple eccrine hidrocystomas. J Eur Acad Dermatol Venereol. 2002;16:288-90.

4. Ankad BS, Domble V, Sujana L. Dermoscopy of apocrine hydrocystoma: A first case report. Our Dermatol Online 2015;6:334-6.

5. Ovhal AG, Deshkulkarani SV, Abhange RS, Birare SD. Rare Benign Cystic Lesions on Face: Apocrine Hidrocystoma. Indian J Dermatol. 2016;61:237.

6. Lipinski SW, Treloar M. Case of Eccrine hidrocystomas of the vulva. Proc Obstet Gynecol. 2016;6:3.

7. Gandhi V, Naik G, Verma P. Eccrine Hidrocystoma Successfully Treated with Topical Synthetis Botulinum Peptide. J Cutan Aesthetic Surg. 2011;4:154-5.

Copyright by Chandramohan Kudligi, et al. This is an open-access article distributed under the terms of the Creative Commons Attribution License, which permits unrestricted use, distribution, and reproduction in any

medium, provided the original author and source are credited.

Source of Support: Nil, Conflict of Interest: None declared. 